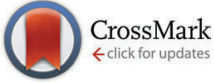

Cite this: New J. Chem., 2015 39, 7602

\title{
Activation of carbon dioxide by new mixed sandwich uranium(III) complexes incorporating cyclooctatetraenyl and pyrrolide, phospholide, or arsolide ligands $\uparrow$
}

\author{
Rachel J. Kahan, ${ }^{a}$ F. Geoffrey N. Cloke, ${ }^{\text {a }}$ S. Mark Roe ${ }^{a}$ and François Nief ${ }^{b}$
}

A series of uranium(III) mixed-sandwich complexes of the type $\left[U\left(C O T^{T I P S 2}\right)\left(C p^{E M e 4}\right)\right]\left(C p^{E M e} 4=E C_{4} M_{4}\right.$, $E$ is $N, P$ or $A s$, and $C O T^{T I P S 2}=\mathrm{C}_{8} \mathrm{H}_{6}\left\{1,4-\mathrm{Si}^{i} \mathrm{Pr}_{3}\right\}$ ), featuring a heterocyclic five membered ring, have been synthesised and their $\mathrm{X}$-ray crystal structures determined. The redox properties of these complexes have been assessed using cyclic voltammetry and the results compared to the purely carbocyclic mixedsandwich analogues. The reactions of $\left[U\left(C O T^{\mathrm{TIPS} 2}\right)\left(\mathrm{Cp}^{\mathrm{NMe} 4}\right)\right]$ and $\left[\mathrm{U}\left(\mathrm{COT}^{\mathrm{TIPS}}\right)\left(\mathrm{Cp}^{\mathrm{PMe} 4}\right)\right]$ with $\mathrm{CO}_{2}$ afford the structurally characterised carbamate and phosphacarbonate complexes $\left[U\left(C O T^{T I P S}\right)\right]_{2}(\mu-O)\left(\mu-\eta^{1}: \eta^{1}\right.$ -

$\left.\mathrm{O}_{2} \mathrm{CEC}_{4} \mathrm{Me}_{4}\right)_{2}\left(\mathrm{E}=\mathrm{N}\right.$ and $\mathrm{P}$ respectively), arising from $\mathrm{CO}_{2}$ reduction and insertion.

Received (in Montpellier, France) 9th March 2015,

Accepted 21st April 2015

DOI: 10.1039/c5nj00590f

www.rsc.org/njc

\section{Introduction}

The use of carbocyclic aromatic ligands in organouranium chemistry has been prominent ever since the synthesis of $\left[\mathrm{Cp}_{3} \mathrm{UCl}\right]$ in $1956,{ }^{1}$ and subsequent expansion of this area to include 6, 7 and 8 membered rings illustrates the versatility of aromatic ligands in this field. The cyclopentadienyl (Cp) ligand and its substituted derivatives are ubiquitous in organouranium chemistry, ${ }^{2}$ however aromatic heterocyclic analogues have received comparatively little attention. Of the few reported uranium complexes featuring heterocyclic 5-membered rings, we reported the only example of a homoleptic uranium complex, featuring the 1,3-di-tert-butyl-1,2,4-triphospholyl ligand, ${ }^{3}$ and more extensive studies by Ephritikhine et al. have employed the tetramethylphospholyl $\left(\mathrm{Cp}^{\mathrm{PMe} 4}\right)$ ligand, as this bears the most resemblance to $\mathrm{Cp}^{*}{ }^{4,5}$ The latter results also demonstrated that these ligands can also bond through the pnictogen lone pair, allowing dimerisation of the complexes via $\eta^{1}: \eta^{5}$-coordination. However the $\mathrm{Cp}^{\mathrm{PMe} 4}$ ligand was also observed to be more labile than its cyclopentadienyl analogues, illustrated by the ready protonation of the ligand in a mixed-sandwich complex to generate a uranium(Iv) cation. , $^{6,7}$

In recent years, the use of organometallic uranium complexes for small molecule activation, has attracted significant interest; ${ }^{8}$

\footnotetext{
${ }^{a}$ Department of Chemistry, School of Life Sciences, University of Sussex, Brighton, BN1 9QJ, UK. E-mail:f.g.cloke@sussex.ac.uk

${ }^{b}$ École Polytechnique, CNRS, Route de Saclay, F-91128 Palaiseau, France

$\dagger$ Electronic supplementary information (ESI) available. CCDC 1051779-1051784. For ESI and crystallographic data in CIF or other electronic format see DOI: 10.1039/c5nj00590f
}

in the specific case of $\mathrm{CO}_{2}$, reduction to afford uranium oxo complexes and CO has been achieved previously using U(III) complexes incorporating tripodal tris(aryloxide) ${ }^{9}$ or siloxide ligands, ${ }^{10}$ and disproportionation to $\mathrm{CO}$ and uranium carbonate derivatives has been described for neutral and anionic U(III) siloxide, ${ }^{10}$ and tris(aryloxide) systems. ${ }^{11}$ In recent years, we have employed uranium(III) mixed-sandwich complexes featuring substituted COT and $\mathrm{Cp}$ ligands for the reductive activation of $\mathrm{CO}$ and $\mathrm{CO}_{2}$, and comprehensive studies have determined that the steric properties of the mixed-sandwich complexes dictate the outcome of these reactions. ${ }^{12,13}$ Hence we decided to investigate the effect of changing the electronic properties of these mixed sandwich complexes, and herein we report the results obtained from incorporation of a heterocyclic ring in to the U(III) mixed sandwich motif and subsequent reactivity towards $\mathrm{CO}_{2}$.

\section{Results and discussion}

\section{Synthesis of mixed-sandwich complexes}

The three mixed-sandwich complexes $\left[\mathrm{U}\left(\mathrm{COT}^{\mathrm{TIPS} 2}\right)\left(\mathrm{Cp}^{\mathrm{EMe} 4}\right)\right](\mathrm{E}=$ $\mathrm{N}$ (1), P (2), As (3)) were prepared by successive salt metathesis reactions of $\mathrm{UI}_{3}$ with $\mathrm{K}\left[\mathrm{Cp}^{\mathrm{EMe} 4}\right]$ and $\mathrm{K}_{2}\left[\mathrm{COT}^{\mathrm{TIPS} 2}\right]$ in low to moderate yield (Scheme 1). This 'one-pot' methodology is an adaptation of the synthetic route employed for the synthesis of $\left[\mathrm{U}\left(\mathrm{COT}^{\mathrm{TIPS}}\right)\left(\mathrm{Cp}^{*}\right)(\mathrm{THF})\right]$ and other substituted cyclopentadienyl analogues, although 1-3 are formed less cleanly and in lower yields (16-40\%) than their purely carbocyclic counterparts. ${ }^{12}$

The phospholyl and arsolyl mixed-sandwich complexes (2 and 3) displayed comparable, paramagnetically shifted ${ }^{1} \mathrm{H}$ and ${ }^{29} \mathrm{Si}\left\{{ }^{1} \mathrm{H}\right\}$ NMR spectra, whereas the pyrrolyl mixed-sandwich 


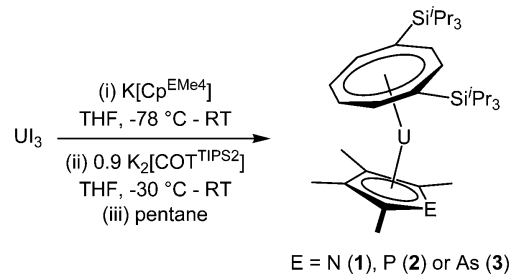

Scheme 1 Synthetic route to uranium(III) mixed-sandwich complexes.

complex 1 displayed a different pattern of proton resonances, indicative of a more complex structure in solution (vide infra). All three complexes form stable adducts with THF, 1.THF, 2-THF, and 3-THF, respectively. Mass spectrometry and microanalysis supported the formulation of 1-3, and the molecular structures were confirmed by single crystal X-ray diffraction studies on the THF complexes, and the structures are shown in Fig. 1 with selected data in Table 1.

High resolution data could not be obtained for $\mathbf{1}$.THF and the molecular structure of this complex therefore only illustrates connectivity. The molecular structure of 2.THF features a phospholyl ring disordered over two positions, which has been modelled accordingly (see ESI $\dagger$ for full details). The three complexes are isostructural, and only small differences are observed between 2.THF and 3.THF, due to the lengthening of the U-E bond on descending the pnictogen group. These structures are similar to their carbocyclic analogue $\left[\mathrm{U}\left(\mathrm{COT}^{\mathrm{TIPS} 2}\right)\left(\mathrm{Cp}^{\mathrm{Me} 4}\right)(\mathrm{THF})\right]$, demonstrating that incorporation of a pnictogen has not significantly altered the overall structural properties of the complexes. Comparison of $\mathbf{2}$. THF to the only other mixed-sandwich complex featuring a heterocyclic ligand, the $\mathrm{U}(\mathrm{Iv})$ complex $\left[\mathrm{U}(\mathrm{COT})\left(\mathrm{Cp}^{\mathrm{PMe} 4}\right)\right.$ $\left.\left(\mathrm{BH}_{4}\right)(\mathrm{THF})\right]$, illustrates a similar $\mathrm{U}-\mathrm{Ct}_{2}$ bond length $(2.610(8)$ A). ${ }^{6}$ However, the $\mathrm{Ct}_{1}-\mathrm{U}-\mathrm{Ct}_{2}$ angle is more acute $\left(135.6(3)^{\circ}\right)$ and the $\mathrm{U}-\mathrm{Ct}_{1}$ distance is longer (2.013(9) $\AA$ ) presumably due to the presence of the $\mathrm{BH}_{4}$ group.

The molecular structure of base-free 1 was also determined by single crystal X-ray diffraction, and shows that this complex is dimeric in the solid-state (see Fig. 2). As a consequence of the dimeric structure, the $\mathrm{Ct}_{1}-\mathrm{U}-\mathrm{Ct}_{2}$ angle is more acute than those in $2 \cdot \mathbf{T H F}$ and $\mathbf{3} \cdot \mathbf{T H F}$, however the $\mathrm{U}-\mathrm{Ct}_{1}, \mathrm{U}-\mathrm{Ct}_{2}$ and $\mathrm{U}-\mathrm{O}$ bond lengths are similar. Other heterocyclic complexes have also been reported featuring $\eta^{5}: \eta^{1}$ coordination, however only
Table 1 Selected distances ( $(\AA)$ and angles $\left(^{\circ}\right)$ for 2.THF and 3.THF. $\mathrm{Ct}_{1}$ is defined as the COT ring centroid and $\mathrm{Ct}_{2}$ is defined as the $\mathrm{Cp}^{\mathrm{EMe} 4}$ ring centroid. Numbers in brackets represent values from the alternatively positioned phospholyl ring

\begin{tabular}{|c|c|c|}
\hline & 2.THF & $3 \cdot \mathbf{T H F}$ \\
\hline $\mathrm{U}-\mathrm{Ct}_{1}$ & $1.9740(4)$ & $1.9744(4)$ \\
\hline $\mathrm{U}-\mathrm{Ct}_{2}$ & $2.54(2)\{2.59(2)\}$ & $2.5962(4)$ \\
\hline U-E & $2.9868(14)\{2.776(15)\}$ & $3.0781(7)$ \\
\hline $\mathrm{U}-\mathrm{O}$ & $2.716(2)$ & $2.726(4)$ \\
\hline $\mathrm{Ct}_{1}-\mathrm{U}-\mathrm{Ct}_{2}$ & $135.8(15)\{142.4(14)\}$ & $141.482(16)$ \\
\hline
\end{tabular}

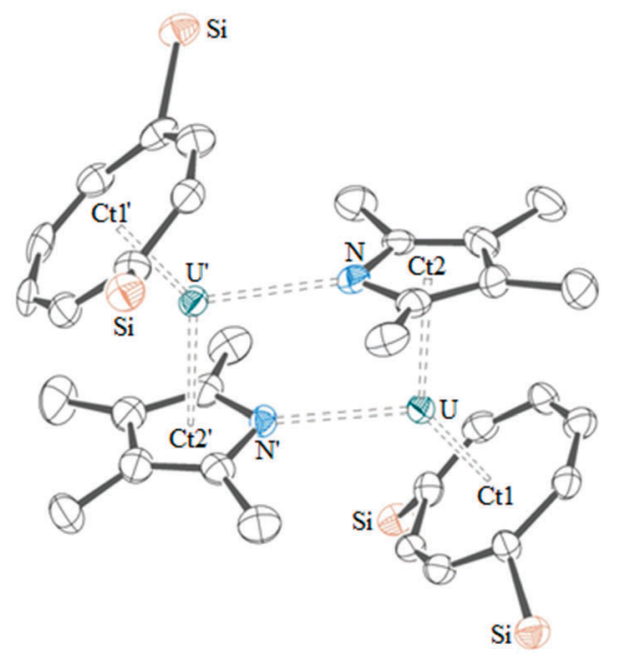

Fig. 2 ORTEP diagram of 1 (thermal ellipsoids at 50\% probability; hydrogen atoms and 'Pr groups have been omitted for clarity). Selected distances ( $(\AA)$ and angles ( $\left.{ }^{\circ}\right): \mathrm{U}_{1}-\mathrm{Ct}_{1} 1.968(3), 1.974(3) ; \mathrm{U}_{1}-\mathrm{Ct}_{2} 2.548(4)$, 2.568(4); $\mathrm{U}_{1}-\mathrm{N}_{1} 2.680(5), 2.691(6) ; \mathrm{U}_{1}-\mathrm{N}_{1}$. 2.598(6), 2.615(5); $\mathrm{Ct}_{1}-\mathrm{U}_{1}-\mathrm{Ct}_{2}$ 138.66(11), 138.55(12).

$\left[\left\{\mathrm{U}\left(\eta^{5}-\mathrm{Cp}^{\mathrm{PMe} 4}\right)\left(\mu-\eta^{5}: \eta^{1}-\mathrm{Cp}^{\mathrm{PMe} 4}\right)\left(\mathrm{BH}_{4}\right)\right\}_{2}\right]$ is comparable to $\mathbf{1 .}^{4}$ The latter features similar U-Ct $t_{2}$ distances (2.56(1) and 2.54(1) $\left.\mathrm{A}\right)$ to 2.THF and similar U-P bond lengths (2.945(3) and 2.995(3) A), demonstrating that $\eta^{1}$-coordination does not affect the $\eta^{5}$-bonding. The dimeric structure of $\mathbf{1}$ presumably persists in solution since it would account for the more complex NMR spectra observed for $\mathbf{1}$ as opposed to those for monomeric 2 and 3; unfortunately DOSY experiments on $\mathbf{1}$ were only suggestive of a dimeric structure and its low solubility in suitable solvents precluded cryoscopy.
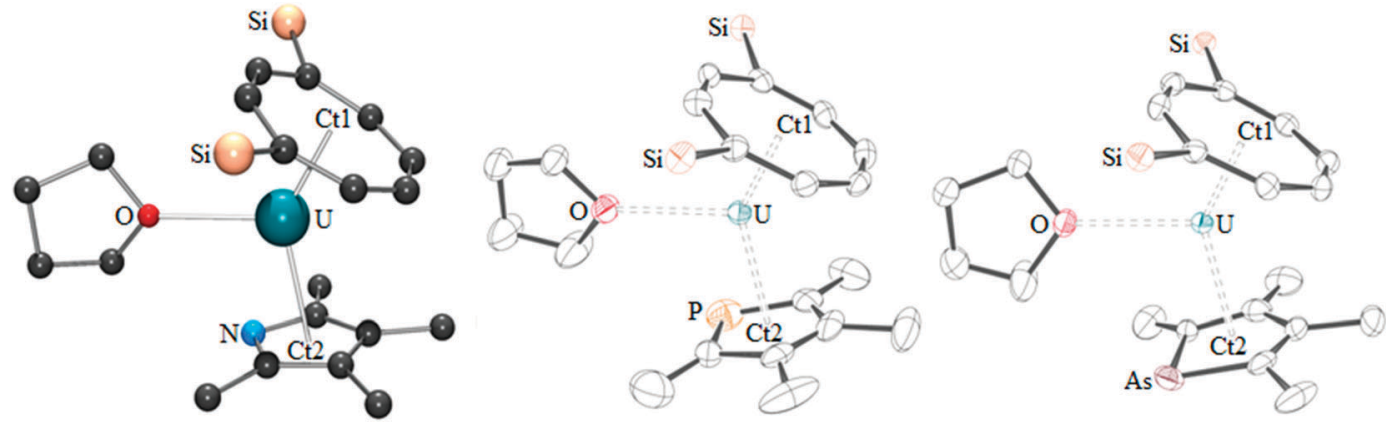

Fig. 1 From left to right: ball and stick model of 1.THF, and ORTEP diagrams of 2.THF and 3.THF (thermal ellipsoids at 50\% probability; hydrogen atoms and $\operatorname{Pr}$ groups have been omitted for clarity). 


\section{Cyclic voltammetry}

In order to compare their $\mathrm{U}^{\mathrm{IV}} / \mathrm{U}^{\mathrm{III}}$ redox couples with the carbocyclic analogues, cyclic voltammetry was performed on 1-3. Complex 1 exhibits a distorted quasi-reversible wave at $-1.88 \mathrm{~V} v s . \mathrm{FeCp}_{2}{ }^{+/ 0}$, which is within the expected range for the $\mathrm{U}^{\mathrm{IV}} / \mathrm{U}^{\mathrm{III}}$ redox couple. Complexes 2 and 3 also exhibit an electrochemical event at this approximate potential. However the degree of distortion of the voltammograms becomes more pronounced descending the pnictogen group, precluding accurate determination of $E_{1 / 2}$. Two other electrochemical events were observed for the three complexes and an additional two events were observed for $\mathbf{1}$ (see ESI $\dagger$ ). These events could however not be unambiguously assigned and demonstrate the complex behaviour of the heteroatom containing mixedsandwich system in the cyclic voltammetry experiment, as opposed to the more straightforward behaviour of the purely carbocyclic complexes. ${ }^{13}$

The assumed $E_{1 / 2}$ value of the $\mathrm{U}^{\mathrm{IV}} / \mathrm{U}^{\mathrm{III}}$ redox couple for $\mathbf{1}$ is slightly less negative than that for $\left[\mathrm{U}\left(\mathrm{COT}^{\mathrm{TIPS}}\right)\left(\mathrm{Cp}^{\mathrm{Me} 4}\right)(\mathrm{THF})\right]$ $(-2.08 \mathrm{~V})$, demonstrating the increased thermodynamic stability of the $\mathrm{U}^{\mathrm{III}}$ oxidation state relative to the $\mathrm{U}^{\mathrm{IV}}$ oxidation state in 1. This is in agreement with other published studies, which found the $\mathrm{U}^{\mathrm{IV}} / \mathrm{U}^{\mathrm{III}}$ redox couple is $c a .0 .2 \mathrm{~V}$ anodically shifted for complexes featuring phospholyl ligands. ${ }^{14}$ This arises from loss of degeneracy of the five-membered ring e-symmetry orbitals, causing a decrease in the HOMO-LUMO gap, an effect which has also been observed in transition metal complexes; ${ }^{15}$ the low
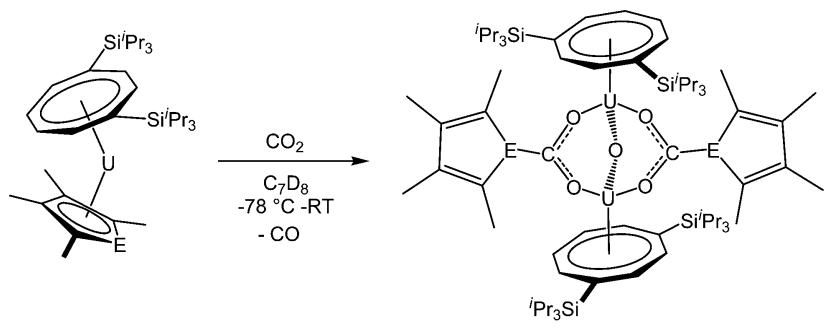

$\mathrm{E}=\mathrm{N}(\mathbf{4})$ or $\mathrm{P}(\mathbf{5})$
Scheme 2 Reactions of $\left[\mathrm{U}\left(\mathrm{COT}^{\mathrm{TIPS}}\right)\left(\mathrm{Cp}^{\mathrm{EMe} 4}\right)\right]$ with $\mathrm{CO}_{2}$. energy vacant orbital in the phospholyl complex $\mathbf{1}$ (and indeed the $\mathrm{N}$ and As analogues) thus likely stabilises the $\mathrm{U}(\mathrm{III})$ centre. Hence, whilst complexes 1-3 can still be regarded as potent reducing agents, they are somewhat less powerful than their purely carbocyclic analogues.

\section{Reactivity with $\mathrm{CO}_{2}$}

Addition of excess carbon dioxide to $\mathbf{1}$ and $\mathbf{2}$ afforded the complexes $\left[\mathrm{U}\left(\mathrm{COT}^{\mathrm{TIPS} 2}\right)\right]_{2}(\mu-\mathrm{O})\left(\mu-\mathrm{O}_{2} \mathrm{CEC}_{4} \mathrm{Me}_{4}\right)_{2}(\mathrm{E}=\mathrm{N}(\mathbf{4}), \mathrm{P}(\mathbf{5}))$, which are formed by reduction of 0.5 equivalents $\mathrm{CO}_{2}$ per uranium centre to give the oxo unit. A further equivalent $\mathrm{CO}_{2}$ is inserted into the $\mathrm{U}-\mathrm{E}$ bond, giving rise to the carbamate and phosphacarbonate units respectively, so that a total of 1.5 equivalents carbon dioxide are required for the transformation (Scheme 2). The reaction can be conveniently monitored by ${ }^{13} \mathrm{C}$ NMR using ${ }^{13} \mathrm{CO}_{2}$, and shows the formation of 4 and 5 by the appearance of resonances at -7.1 and $-46.6 \mathrm{ppm}$ corresponding to the carbamate and phosphacarbonate groups, respectively; free ${ }^{13} \mathrm{CO}$ formed from the reduction of $\mathrm{CO}_{2}$ to form the bridging oxo unit was also observed in both cases.

Monitoring of the formation of 4 in $\mathrm{C}_{7} \mathrm{D}_{8}$ by ${ }^{1} \mathrm{H}$ NMR spectroscopy revealed its formation to be quantitative; however the thermal instability of this complex resulted in consistently low values of carbon by microanalysis, but 4 did display a parent ion in the mass spectrum (EI). The formation of 5 was found to proceed less cleanly and in lower yield. The ${ }^{1} \mathrm{H}$ NMR spectrum of 5 in $\mathrm{C}_{7} \mathrm{D}_{8}$ at $303 \mathrm{~K}$ was broad and with few clearly defined resonances. The spectrum sharpened at $363 \mathrm{~K}$, (possibly due to a fluxional process, the nature of which however could not be established), allowing the assignment of all but the COT ring protons. However, microanalysis and mass spectral data (EI) agreed with the proposed formulation of $\mathbf{5}$. Attempts to react 3 with carbon dioxide were unsuccessful and resulted in decomposition of the complex to form intractable products.

The proposed structures of $\mathbf{4}$ and $\mathbf{5}$ were confirmed by single crystal X-ray diffraction (see Fig. 3 and Table 2), and to the best of our knowledge, 5 represents the first example of a phosphacarbonate ligand bound to a uranium centre. Both complexes are structurally similar, and exhibit slightly shorter $\mathrm{U}-\mathrm{Ct}_{1}$ distances than the parent mixed-sandwich complexes. The oxo unit is
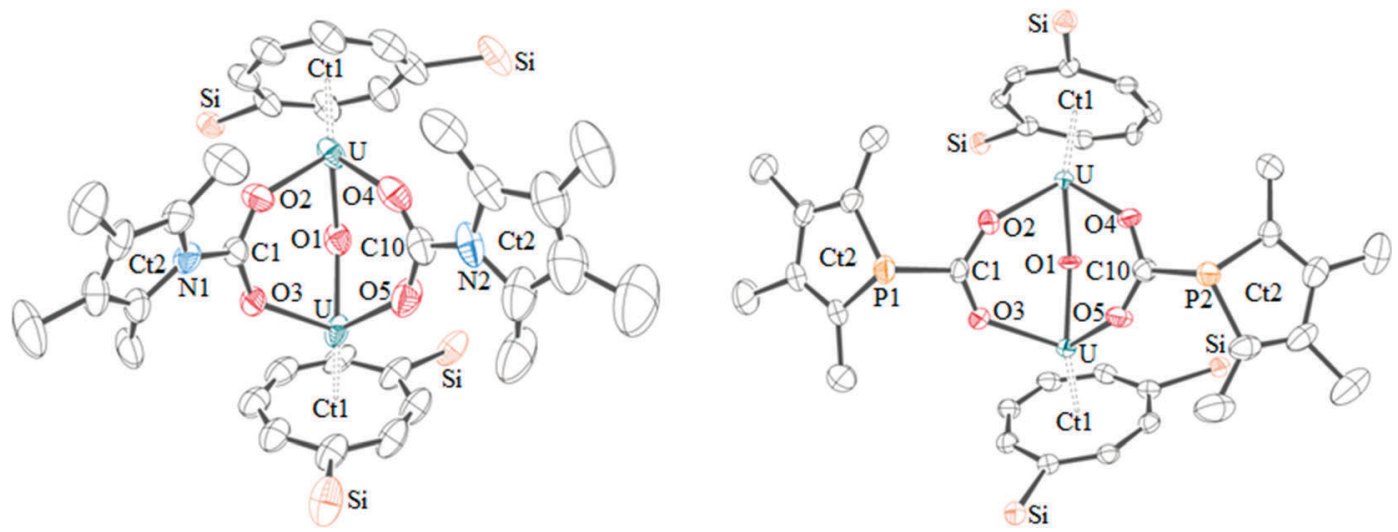

Fig. 3 The molecular structure of $\mathbf{4}$ (left) and $\mathbf{5}$ (right, thermal ellipsoids at 50\% probability. Hydrogen atoms and 'Pr groups have been omitted for clarity). 
Table 2 Selected distances $(\AA)$ and angles $\left(^{\circ}\right)$ for $\mathbf{4}$ and $\mathbf{5}$. $\mathrm{Ct}_{1}$ is defined as the COT ring centroid and $\mathrm{Ct}_{2}$ is defined as the $\mathrm{Cp} \mathrm{p}^{\mathrm{EM} 4}$ ring centroid

\begin{tabular}{lll}
\hline & $\mathbf{4}$ & $\mathbf{5}$ \\
\hline $\mathrm{U}-\mathrm{Ct}_{1}$ & $1.908(12), 1.921(13)$ & $1.9320(3), 1.9323(3)$ \\
$\mathrm{U}-\mathrm{O}_{1}$ & $2.094(7), 2.074(6)$ & $2.096(3), 2.096(3)$ \\
$\mathrm{U}-\mathrm{O}_{2,3,4,5}$ & $2.353(6), 2.350(5), 2.329(7), 2.379(7)$ & $2.346(4), 2.391(4), 2.362(3), 2.343(4)$ \\
$\mathrm{C}_{1,10}-\mathrm{O}_{2,3,4,5}$ & $1.262(10), 1.270(10), 1.256(12), 1.243(12)$ & $1.260(6), 1.262(6), 1.260(6), 1.286(6)$ \\
$\mathrm{C}_{1,10}-\mathrm{E}_{1,2}$ & $1.381(10), 1.381(14)$ & $1.855(6), 1.850(6)$ \\
$\mathrm{U}-\mathrm{O}_{1}-\mathrm{U}$ & $139.4(3)$ & $139.38(19)$
\end{tabular}

symmetrical in $\mathbf{5}$ but asymmetrical in $\mathbf{4}$ despite the identical $\mathrm{U}-\mathrm{O}-\mathrm{U}$ angle, but both complexes feature carboxyl fragments that are positioned off-centre between the two uranium centres. The metrics within this unit closely resemble those in [(OTtbp)$\left.2 \mathrm{U}(\mu-\mathrm{O})\left(\mu-\mathrm{O}_{2} \mathrm{COTtbp}\right)_{2} \mathrm{U}(\mathrm{OTtbp})_{2}\right]$, which also exhibits a bent oxo fragment $\left(140.4(5)^{\circ}\right)$ with identical $\mathrm{U}-\mathrm{O}$ distances to $\mathbf{5}$ (2.095(3) A), and asymmetrical bridging carbonate moieties. ${ }^{16}$

However, some structural differences are observed between the carbamate and phosphacarbonate units. In 4, the nitrogen lone pair overlaps with the $\mathrm{CO}_{2}$ unit, evidenced by the short $\mathrm{N}-\mathrm{CO}_{2}$ bonds, and with the pyrrolyl diene unit, which gives rise to near linear $\mathrm{Ct}_{2}-\mathrm{N}-\mathrm{C}$ angles (169.1(13) and 179.6(12) ${ }^{\circ}$ ), and a delocalised carbamate moiety with an aromatic pyrrolyl ring. The phosphacarbonate fragment in $\mathbf{5}$ does not exhibit this feature, and has discrete diene and $\mathrm{P}-\mathrm{CO}_{2}$ moieties and bent $\mathrm{Ct}_{2}-\mathrm{P}-\mathrm{C}$ angles (116.6(2) and 116.2(3) $\left.{ }^{\circ}\right)$, with trigonal pyramidal geometry around the phosphorus atoms.

\section{Conclusion}

Three new mixed-sandwich complexes of the type [U(COT $\left.{ }^{\mathrm{TIPS}}\right)$ $\left.\left(\mathrm{Cp}^{\mathrm{EMe} 4}\right)\right]$ (where $\mathrm{E}$ is $\mathrm{N}$, $\mathrm{P}$ or As and $\mathrm{COT}^{\mathrm{TIPS} 2}=\mathrm{C}_{8} \mathrm{H}_{6}\left\{1,4-\mathrm{Si}^{\mathrm{i}} \mathrm{Pr}_{3}\right\}$ ) have been synthesised featuring a heterocyclic alternative to the cyclopentadienyl ligand. These complexes are structurally comparable to their purely carbocyclic analogues, but feature slightly less negative $\mathrm{U}^{\mathrm{IV}} / \mathrm{U}^{\mathrm{III}}$ redox potentials as a result of the heteroatom incorporation in to the 5-membered ring. However, they are still capable of reducing $\mathrm{CO}_{2}$, but the presence of the heteroatom also results in $\mathrm{CO}_{2}$ insertion chemistry and the formation of the first uranium phosphacarbonate complex.

\section{Experimental}

\section{General considerations}

All manipulations were carried out under an inert atmosphere of argon using standard Schlenk techniques or under an argon atmosphere in an MBraun glovebox. Solvents were dried over appropriate drying agents $\left(\mathrm{NaK}_{3}\right.$, pentane; K, THF) prior to distillation under $\mathrm{N}_{2}$. Solvents were stored over K mirrors or $4 \AA$ molecular sieves. Deuterated solvents were dried over K, vacuum distilled and stored over 4 A molecular sieves under Ar. NMR spectra were recorded on a Varian VNMR spectrometer operating at $400 \mathrm{MHz}\left({ }^{1} \mathrm{H}\right) .{ }^{1} \mathrm{H}$ and ${ }^{13} \mathrm{C}$ spectra were referenced internally to residual solvent signals, ${ }^{28} \mathrm{Si}$ spectra were referenced externally to $\mathrm{SiMe}_{4}$ and ${ }^{31} \mathrm{P}$ spectra were referenced externally to $85 \% \mathrm{H}_{3} \mathrm{PO}_{4}$ in $\mathrm{D}_{2} \mathrm{O}$. EI-MS was performed by
Dr A. K. Abdul-Sada at the University of Sussex using a VG Autospec Fisons instrument. Elemental analyses were performed by Mikroanalytisches Labor Pascher or the University of Bristol Microanalysis Service. IR Spectra were recorded on residues between $\mathrm{NaCl}$ plates on a Perkin-Elmer Spectrum One FTIR instrument. The following materials were prepared according to published procedures: $\mathrm{UI}_{3},{ }^{17}$ potassium tetramethylphospholyl (referred to as $\left.\left.\mathrm{K}\left[\mathrm{Cp}^{\mathrm{PMe} 4}\right]\right)\right)^{5,18}$ Potassium tetramethylpyrrolyl (referred to as $\mathrm{K}\left[\mathrm{Cp}^{\mathrm{NMe} 4}\right]$ ), ${ }^{19}$ potassium tetramethylarsolyl (referred to as $\mathrm{K}\left[\mathrm{Cp}^{\mathrm{AsMe} 4}\right]$ ), ${ }^{20}$ and $\mathrm{K}_{2}\left[\mathrm{C}_{8} \mathrm{H}_{6}\left\{1,4-\mathrm{Si}^{\mathrm{i}} \mathrm{Pr}_{3}\right\}\right]$ (referred to as $\mathrm{K}_{2}\left[\mathrm{COT}^{\text {TIPS2}}\right] \cdot{ }^{21}{ }^{13} \mathrm{CO}_{2}$ (99\% enrichment) was purchased from Cambridge Isotopes and transferred via a calibrated Toepler pump.

\section{Syntheses}

$\left[\mathbf{U}\left(\mathbf{C O T}^{\text {TIPS2}}\right)\left(\mathbf{C p}^{\text {NMe4 }}\right)\right]$ (1). THF $(150 \mathrm{~mL})$ was added to a mixture of $\mathrm{UI}_{3}\left(1.240 \mathrm{~g}, 2.000 \times 10^{-3} \mathrm{~mol}\right)$ and $\mathrm{K}\left[\mathrm{Cp}^{\mathrm{NMe} 4}\right](0.335 \mathrm{~g}$, $\left.2.08 \times 10^{-3} \mathrm{~mol}\right)$ at $-78{ }^{\circ} \mathrm{C}$. The mixture was slowly warmed to ambient temperature and stirred overnight. The solution was cooled to $-35^{\circ} \mathrm{C}$, and to this was added a solution of $\mathrm{K}_{2}\left[\mathrm{COT}^{\mathrm{TIPS}}\right]$ $(0.865 \mathrm{~g}, 1.75 \mathrm{mmol})$ in THF $(50 \mathrm{~mL})$ dropwise over $40 \mathrm{~m}$. The mixture was warmed to ambient temperature and dried under reduced pressure, then extracted in pentane and filtered through Celite to yield a green/brown solution. Cooling the solution to $-35{ }^{\circ} \mathrm{C}$ afforded deep brown crystals of $1(0.243 \mathrm{~g}$, 16\%). ${ }^{1} \mathrm{H}$ NMR $\left(\mathrm{C}_{7} \mathrm{D}_{8}\right): \delta 1.7$ (s, br, $\left.18 \mathrm{H},{ }^{\mathrm{i}} \mathrm{Pr}-\mathrm{CH}_{3}\right), 1.1$ (s, br, $6 \mathrm{H}$, $\left.{ }^{\mathrm{i}} \operatorname{Pr}-\mathrm{CH}\right),-0.5$ (s, br, 18H, $\left.{ }^{\mathrm{i}} \mathrm{Pr}-\mathrm{CH}_{3}\right),-5.5$ (s, br, 2H, COT-CH), -6.4 (s, br, 6H, Cp-CH $H_{3},-43.9$ (s, br, 2H, COT-CH), -60.4 (s, br, 2H, COT-CH), -60.9 (s, br, Cp-C $\left.H_{3}\right) .{ }^{29} \mathrm{Si}\left\{{ }^{1} \mathrm{H}\right\} \mathrm{NMR}\left(\mathrm{C}_{7} \mathrm{D}_{8}\right)$ : $\delta-139.6\left(\mathrm{Si}^{\mathrm{i}} \mathrm{Pr}_{3}\right)$. Anal. calcd (found) for $\mathrm{C}_{34} \mathrm{H}_{60} \mathrm{NSi}_{2} \mathrm{U}$ : C 52.55 (52.73), N 1.80 (1.85), H 7.78 (7.77). MS (EI): $m / z=776\left(\mathrm{M}^{+}\right)$. X-ray quality crystals of $\mathbf{1}$. THF were obtained from a saturated pentane/THF solution at $-35{ }^{\circ} \mathrm{C} .{ }^{1} \mathrm{H}$ NMR $\left(\mathrm{C}_{7} \mathrm{D}_{8}\right): \delta 8.4(\mathrm{~s}, \mathrm{br}$, 2H, COT-CH), 3.4 (s, br, Cp-CH $H_{3}$ ), 3.2 (s, br, 4H, THF), -1.3 (s, br, 4H, THF), -1.1 (s, br, 6H, $\left.{ }^{\mathrm{i}} \operatorname{Pr}-\mathrm{CH}\right),-2.2(\mathrm{br}, 24 \mathrm{H}$, $\left.{ }^{\mathrm{i}} \mathrm{Pr}-\mathrm{CH}_{3}\right),-4.0$ (s, br, $\left.18 \mathrm{H},{ }^{\mathrm{i}} \mathrm{Pr}-\mathrm{CH}_{3}\right),-34.9$ (s, br, $\left.\mathrm{Cp}-\mathrm{CH}_{3}\right)$, -75.0 (s, br, 2H, COT-CH), -91.4 (s, br, 2H, COT-CH). ${ }^{29} \mathrm{Si}\left\{{ }^{1} \mathrm{H}\right\}$ $\operatorname{NMR}\left(\mathrm{C}_{7} \mathrm{D}_{8}\right): \delta-141.6\left(\mathrm{Si}^{\mathrm{i}} \mathrm{Pr}_{3}\right)$.

[U(COT $\left.\left.{ }^{\text {TIPS2}}\right)\left(\mathbf{C p}^{\text {PMe4}}\right)\right]$ (2). A solution of $\mathrm{K}\left[\mathrm{Cp}^{\mathrm{PMe} 4}\right](0.178 \mathrm{~g}$, $\left.0.998 \times 10^{-3} \mathrm{~mol}\right)$ in THF $(30 \mathrm{~mL})$ was added to a suspension of $\mathrm{UI}_{3}\left(0.618 \mathrm{~g}, 0.999 \times 10^{-3} \mathrm{~mol}\right)$ in THF $(60 \mathrm{~mL})$, resulting in a colour change from deep blue to green over several minutes. The mixture was stirred for a minimum of $2 \mathrm{~h}$ then cooled to $-40{ }^{\circ} \mathrm{C}$. To this was added a solution of $\mathrm{K}_{2}\left[\mathrm{COT}^{\mathrm{TIPS}}\right](0.430 \mathrm{~g}$, $\left.0.869 \times 10^{-3} \mathrm{~mol}\right)$ in THF $(30 \mathrm{~mL})$ dropwise over 20 minutes. The mixture was warmed to ambient temperature and dried 
under reduced pressure, then extracted in pentane and filtered through Celite to yield a brown solution. Cooling the solution to $-35{ }^{\circ} \mathrm{C}$ yielded 2 as a purple powder $(0.281 \mathrm{~g}, 32 \%) .{ }^{1} \mathrm{H}$ NMR $\left(\mathrm{C}_{7} \mathrm{D}_{8}\right): \delta 34.3(\mathrm{~s}, \mathrm{br}, 2 \mathrm{H}, \mathrm{COT}-\mathrm{CH}),-1.7\left(\mathrm{~s}, \mathrm{br}, 6 \mathrm{H},{ }^{\mathrm{i}} \mathrm{Pr}-\mathrm{CH}\right),-4.6$ $\left(\mathrm{s}, \mathrm{br}, 18 \mathrm{H},{ }^{\mathrm{i}} \mathrm{Pr}-\mathrm{CH}_{3}\right),-8.1$ (s, br, $\left.18 \mathrm{H},{ }^{\mathrm{i}} \mathrm{Pr}-\mathrm{CH}_{3}\right),-13.4$ (s, br, $6 \mathrm{H}$, $\mathrm{Cp}-\mathrm{CH}_{3}$ ), -35.4 (s, br, Cp- $\mathrm{CH}_{3}$ ), -72.5 (s, br, 2H, COT-CH), -106.8 (s, br, 2H, COT-CH). ${ }^{29} \mathrm{Si}\left\{{ }^{1} \mathrm{H}\right\} \mathrm{NMR}\left(\mathrm{C}_{7} \mathrm{D}_{8}\right): \delta-120.3$ $\left(\mathrm{Si}^{\mathrm{i}} \mathrm{Pr}_{3}\right) .{ }^{31} \mathrm{P}\left\{{ }^{1} \mathrm{H}\right\}$ NMR $\left(\mathrm{C}_{7} \mathrm{D}_{8}\right): \delta 910.6\left(\mathrm{br}, w_{1 / 2}=1433 \mathrm{~Hz}\right.$, P-'ring'). Anal. calcd (found) for $\mathrm{C}_{34} \mathrm{H}_{60} \mathrm{Si}_{2} \mathrm{PU}$ : C 51.43 (51.57), H 7.62 (7.69). MS (EI): $m / z=794\left(\mathrm{M}^{+}\right)$. Addition of THF $(0.5 \mathrm{~mL})$ to a saturated pentane solution of 2 yielded crystals of $2 \cdot \mathbf{T H F}$ at $-35{ }^{\circ} \mathrm{C} .{ }^{1} \mathrm{H}$ NMR $\left(\mathrm{C}_{7} \mathrm{D}_{8}\right): \delta 14.9(\mathrm{~s}, \mathrm{br}, 2 \mathrm{H}, \mathrm{COT}-\mathrm{CH}), 1.8(\mathrm{~s}, \mathrm{br}$, $4 \mathrm{H}, \mathrm{THF}), 0.8$ (s, br, 4H, THF), -1.8 (s, br, 6H, $\left.{ }^{\mathrm{i}} \mathrm{Pr}-\mathrm{CH}\right),-3.0$ (br, $24 \mathrm{H},{ }^{\mathrm{i}} \mathrm{Pr}-\mathrm{CH}_{3}, \mathrm{Cp}-\mathrm{CH}_{3}$ ), -4.8 (s, br, $18 \mathrm{H},{ }^{\mathrm{i}} \mathrm{Pr}-\mathrm{CH}_{3}$ ), -25.7 (s, br, Cp-CH $H_{3}$ ) -73.0 (s, br, 2H, COT-CH), -83.4 (s, br, $2 \mathrm{H}$, COT-C $H).) .{ }^{29} \mathrm{Si}\left\{{ }^{1} \mathrm{H}\right\}$ NMR $\left(\mathrm{C}_{7} \mathrm{D}_{8}\right): \delta-127.5\left(S i^{\mathrm{i}} \mathrm{Pr}_{3}\right) \cdot{ }^{31} \mathrm{P}\left\{{ }^{1} \mathrm{H}\right\}$ NMR $\left(\mathrm{C}_{7} \mathrm{D}_{8}\right): \delta 846.2$ (br, $w_{1 / 2}=411 \mathrm{~Hz}, \mathrm{P}$-'ring').

[U(COT $\left.\left.{ }^{\text {TIPS2}}\right)\left(\mathbf{C p}^{\text {AsMe4}}\right)\right]$ (3). THF $(80 \mathrm{~mL})$ was added to a mixture of $\mathrm{UI}_{3}\left(0.592 \mathrm{~g}, 0.956 \times 10^{-3} \mathrm{~mol}\right)$ and $\mathrm{K}\left[\mathrm{Cp}^{\mathrm{AsMe} 4}\right]$ $\left(0.213 \mathrm{~g}, 0.958 \times 10^{-3} \mathrm{~mol}\right)$ at $-78{ }^{\circ} \mathrm{C}$. The mixture was slowly warmed to ambient temperature and stirred overnight. The solution was cooled to $-40{ }^{\circ} \mathrm{C}$, and to this was added a solution of $\mathrm{K}_{2}\left[\mathrm{COT}^{\mathrm{TIPS} 2}\right]\left(0.370 \mathrm{~g}, 0.747 \times 10^{-3} \mathrm{~mol}\right)$ in THF $(50 \mathrm{~mL})$ dropwise over $30 \mathrm{~m}$. The mixture was warmed to ambient temperature and dried under reduced pressure, then extracted in pentane and filtered through Celite to yield a brown solution. Cooling the solution to $-35{ }^{\circ} \mathrm{C}$ yielded 3 as a brown powder $(0.320 \mathrm{~g}, 40 \%) .{ }^{1} \mathrm{H}$ NMR $\left(\mathrm{C}_{7} \mathrm{D}_{8}\right): \delta 35.3$ (s, br, 2H, COT$\mathrm{CH}$ ), -1.6 (s, br, 6H, $\left.{ }^{\mathrm{i}} \mathrm{Pr}-\mathrm{CH}\right),-4.2$ (s, br, $\left.18 \mathrm{H},{ }^{\mathrm{i}} \mathrm{Pr}-\mathrm{CH}_{3}\right),-7.6$ (s, br, $\left.18 \mathrm{H},{ }^{\mathrm{i}} \mathrm{Pr}-\mathrm{CH}_{3}\right),-13.9$ (s, br, 6H, Cp-CH $),-41.0$ (s, br, Cp$\mathrm{CH}_{3}$ ) -71.7 (s, br, 2H, COT-CH), -105.8 (s, br, 2H, COT-CH). ${ }^{29} \mathrm{Si}\left\{{ }^{1} \mathrm{H}\right\}$ NMR $\left(\mathrm{C}_{7} \mathrm{D}_{8}\right): \delta-116.3\left(\mathrm{Si}^{\mathrm{i}} \mathrm{Pr}_{3}\right)$. Anal. calcd (found) for $\mathrm{C}_{34} \mathrm{H}_{60} \mathrm{Si}_{2} \mathrm{AsU}$ : C 48.73 (48.29), $\mathrm{H} 7.22$ (7.33). MS (EI): $\mathrm{m} / \mathrm{z}=$ $837\left(\mathrm{M}^{+}\right) .{ }^{1} \mathrm{H}$ NMR $\left(\mathrm{C}_{7} \mathrm{D}_{8}\right): \delta 15.4(\mathrm{~s}, \mathrm{br}, 2 \mathrm{H}, \mathrm{COT}-\mathrm{CH}), 2.5(\mathrm{~s}, \mathrm{br}$, $4 \mathrm{H}, \mathrm{THF}), 1.1$ (s, br, $4 \mathrm{H}, \mathrm{THF}),-1.7$ (s, br, $\left.6 \mathrm{H},{ }^{\mathrm{i}} \operatorname{Pr}-\mathrm{CH}\right),-2.8$ (br, $24 \mathrm{H},{ }^{\mathrm{i}} \mathrm{Pr}-\mathrm{CH}_{3}$ ), -3.2 (s, br, $\left.\mathrm{Cp}-\mathrm{CH}_{3}\right)-4.6$ (s, br, $18 \mathrm{H},{ }^{\mathrm{i}} \mathrm{Pr}-\mathrm{CH}_{3}$ ), -28.7 (s, br, Cp-CH $\left.H_{3}\right),-72.6(\mathrm{~s}, \mathrm{br}, 2 \mathrm{H}, \mathrm{COT}-\mathrm{CH}),-80.5$ (s, br, $2 \mathrm{H}, \mathrm{COT}-\mathrm{CH}) .{ }^{29} \mathrm{Si}\left\{{ }^{1} \mathrm{H}\right\}$ NMR $\left(\mathrm{C}_{7} \mathrm{D}_{8}\right): \delta-126.5\left(\mathrm{Si}^{\mathrm{i}} \mathrm{Pr}_{3}\right)$.

$\left[\mathbf{U}\left(\mathbf{C O T}^{\mathrm{TIPS} 2}\right)\right]_{2}(\boldsymbol{\mu}-\mathrm{O})\left(\boldsymbol{\mu}-\boldsymbol{\eta}^{\mathbf{1}}: \boldsymbol{\eta}^{\mathbf{1}}-\mathbf{O}_{2} \mathbf{C N C}_{\mathbf{4}} \mathbf{M e}_{4}\right)_{\mathbf{2}} \quad$ (4). An excess (3 equivalents) ${ }^{13} \mathrm{CO}_{2}$ was delivered to a solution of 1 (34.2 mg, $4.40 \times 10^{-5} \mathrm{~mol}$ ) in $\mathrm{C}_{7} \mathrm{D}_{8}$ via Toepler pump at $-78^{\circ} \mathrm{C}$. Warming of the solution to ambient temperature resulted in a gradual colour change from brown to orange over $24 \mathrm{~h}$. Removal of all volatiles under reduced pressure afforded an orange residue, which was extracted in hexane and cooled to $-35{ }^{\circ} \mathrm{C}$ to yield crystals of $4(22.7 \mathrm{mg}, 62 \%)$. NMR $\left(\mathrm{C}_{7} \mathrm{D}_{8}\right): \delta-1.4(\mathrm{~s}, \mathrm{br}, 18 \mathrm{H}$, $\left.{ }^{\mathrm{i}} \mathrm{Pr}-\mathrm{CH}_{3}\right),-2.3\left(\mathrm{~s}, \mathrm{br}, 6 \mathrm{H},{ }^{\mathrm{i}} \mathrm{Pr}-\mathrm{CH}\right),-2.6\left(\mathrm{~s}, \mathrm{br}, 18 \mathrm{H},{ }^{\mathrm{i}} \mathrm{Pr}-\mathrm{CH}_{3}\right)$, -10.0 (s, br, 6H, Cp-CH $H_{3}$, -27.7 (s, br, 6H, Cp-CH $H_{3}$. COT ring proton resonances were not observed. ${ }^{13} \mathrm{C}\left\{{ }^{1} \mathrm{H}\right\}$ NMR $\left(\mathrm{C}_{7} \mathrm{D}_{8}\right): \delta$ -7.1 (s, $\left.\mathrm{O}_{2}{ }^{13} \mathrm{CNC}_{4} \mathrm{Me}_{4}\right) .{ }^{29} \mathrm{Si}\left\{{ }^{1} \mathrm{H}\right\}$ NMR $\left(\mathrm{C}_{7} \mathrm{D}_{8}\right): \delta-79.7\left(\mathrm{Si}^{\mathrm{i}} \mathrm{Pr}_{3}\right)$. Anal. calcd (found) for $\mathrm{C}_{68}{ }^{13} \mathrm{C}_{2} \mathrm{H}_{120} \mathrm{O}_{5} \mathrm{~N}_{2} \mathrm{Si}_{4} \mathrm{U}_{2}$ : C 50.76 (49.527), $\mathrm{H} 7.29$ (7.201), N 1.69 (2.100). The low percentage of $\mathrm{C}$ and high percentage of $\mathrm{N}$ is attributed to the limited thermal stability of 4. $\mathrm{MS}$ (EI): $m / z=1659\left(\mathrm{M}^{+}\right)$.

$\left[\mathbf{U}\left(\mathbf{C O T}^{\mathrm{TIPS} 2}\right)\right]_{2}(\boldsymbol{\mu}-\mathrm{O})\left(\boldsymbol{\mu}-\boldsymbol{\eta}^{\mathbf{1}}: \boldsymbol{\eta}^{\mathbf{1}}-\mathbf{O}_{\mathbf{2}} \mathbf{C P C}_{\mathbf{4}} \mathbf{M e}_{\mathbf{4}}\right)_{\mathbf{2}}$ (5). A solution of $\mathbf{2}$ $\left(191.5 \mathrm{mg}, 2.21 \times 10^{-4} \mathrm{~mol}\right)$ in pentane was frozen and exposed to 3.2 equivalents $\mathrm{CO}_{2}$ via Toepler pump. Warming the solution to ambient temperature resulted in a gradual colour change from purple to red/brown. Solution was stirred for $24 \mathrm{~h}$ then filtered via filter cannula. Cooling the solution to $-35{ }^{\circ} \mathrm{C}$ afforded crystals of 5 (47.5 mg, 25\%). Repetition of the reaction with ${ }^{13} \mathrm{CO}_{2}$ afforded the ${ }^{13} \mathrm{C}$-enriched complex. ${ }^{1} \mathrm{H}$ NMR $\left(\mathrm{C}_{7} \mathrm{D}_{8}\right.$ at $363 \mathrm{~K}): 1.8\left(\mathrm{~s}, \mathrm{br}, 6 \mathrm{H}, \mathrm{Cp}-\mathrm{CH}_{3} /{ }^{\mathrm{i}} \mathrm{Pr}-\mathrm{CH}\right), 0.9$ (s, br, $18 \mathrm{H},{ }^{\mathrm{i}} \mathrm{Pr}-$ $\mathrm{CH}_{3}$ ), 0.2 (s, br, $\left.18 \mathrm{H},{ }^{\mathrm{i}} \mathrm{Pr}-\mathrm{CH}_{3}\right),-7.3$ (s, br, $6 \mathrm{H}, \mathrm{Cp}-\mathrm{CH}_{3} /{ }^{\mathrm{i}} \mathrm{Pr}-\mathrm{CH}$ ), -15.0 (s, br, 6H, Cp-CH $\left.3{ }^{\mathrm{i}} \mathrm{Pr}-\mathrm{CH}\right) .{ }^{13} \mathrm{C}\left\{{ }^{1} \mathrm{H}\right\} \mathrm{NMR}\left(\mathrm{C}_{7} \mathrm{D}_{8}\right):-46.6$ $\left(\mathrm{d},{ }^{1} J_{\mathrm{CP}}=20.3 \mathrm{~Hz}, \mathrm{O}_{2}{ }^{13} \mathrm{CPC}_{4} \mathrm{Me}_{4}\right) .{ }^{29} \mathrm{Si}\left\{{ }^{1} \mathrm{H}\right\} \mathrm{NMR}\left(\mathrm{C}_{7} \mathrm{D}_{8}\right): \delta-75.7$ $\left(\mathrm{Si}^{\mathrm{i}} \mathrm{Pr}_{3}\right) .{ }^{31} \mathrm{P}\left\{{ }^{1} \mathrm{H}\right\}$ NMR $\left(\mathrm{C}_{7} \mathrm{D}_{8}\right): \delta$ 15.0-9.0 (br, overlapping, P-'ring'), -14.5 (br, P-'ring'). Anal. calcd (found) for $\mathrm{C}_{70} \mathrm{H}_{120} \mathrm{O}_{5} \mathrm{P}_{2} \mathrm{Si}_{4} \mathrm{U}_{2}$ : C 49.69 (49.937), $\mathrm{H} 7.15$ (7.332). MS (EI): $m / z=1692\left(\mathbf{M}^{+}\right)$.

\section{X-ray crystallographic studies}

Data for 1, 2, 3 and 5 were collected on a Enraf-Nonius CAD4 diffractometer with graphite-monochromated Mo K $\alpha$ radiation $(\lambda=0.71073)$ source, and data for $\mathbf{1} \cdot \mathbf{T H F}$ were collected using a Agilent Technologies Xcalibur Gemini ultra diffractometer with a $\mathrm{Cu} \mathrm{K} \alpha$ radiation $(\lambda=1.54184)$ source at $173 \mathrm{~K}$ using an Oxford Cryosystems Cobra low temperature device, operating in $\omega$ scanning mode with $\Psi$ and $\omega$ scans to fill the Ewald sphere. The programs used for control and integration were Collect, ${ }^{22}$ Scalepack and Denzo. ${ }^{23}$ Absorption corrections were based on equivalent reflections using SADABS. ${ }^{24}$ Data for $\mathbf{4}$ were collected and processed by the UK National Crystallography Service at the University of Southampton. ${ }^{25}$ The crystals were mounted on a glass fibre with silicon grease, from dried vacuum oil kept over $4 \AA$ molecular sieves in an MBraun glovebox under Ar. All solutions and refinements were performed using the WinGX or Olex2 packages and software therein. All non-hydrogen atoms were refined with anisotropic displacement parameters and all hydrogen atoms were refined using a riding model. Disordered solvent molecules were modelled using the SQUEEZE ${ }^{26}$ function in PLATON. ${ }^{27}$ Crystal structure and refinement data are given in Table S1 of the ESI. $\dagger$ CCDC 1051779-1051784.

\section{Acknowledgements}

We thank the European Research Council (F.G.N.C.), the EPSRC, and the Ivor Nixon Fund (R.J.K.) for financial support. We also thank Dr A. Abdul-Sada (University of Sussex) for mass spectrometry.

\section{References}

1 L. T. Reynolds and G. Wilkinson, J. Inorg. Nucl. Chem., 1956, 2, 246-253.

2 M. Ephritikhine, Organometallics, 2013, 32, 2464-2488.

3 G. K. B. Clentsmith, F. G. N. Cloke, M. D. Francis, J. R. Hanks, P. B. Hitchcock and J. F. Nixon, J. Organomet. Chem., 2008, 693, 2287-2292.

4 P. Gradoz, M. Ephritikhine, M. Lance, J. Vigner and M. Nierlich, J. Organomet. Chem., 1994, 481, 69-73. 
5 P. Gradoz, D. Baudry, M. Ephritikhine, F. Nief and F. Mathey, J. Chem. Soc., Dalton Trans., 1992, 3047-3051; P. Gradoz, C. Boisson, D. Baudry, M. Lance, M. Nierlich, J. Vigner and M. Ephritikhine, J. Chem. Soc., Chem. Commun., 1992, 1720-1721; P. Gradoz, D. Baudry, M. Ephritikhine, M. Lance, M. Nierlich and J. Vigner, J. Organomet. Chem., 1994, 466, 107-118.

6 S. M. Cendrowski-Guillaume, M. Nierlich and M. Ephritikhine, J. Organomet. Chem., 2002, 643-644, 209-213.

7 S. M. Cendrowski-guillaume, G. Le Gland, M. Nierlich and M. Ephritikhine, Eur. J. Inorg. Chem., 2003, 1388-1393.

8 For recent reviews see: P. L. Arnold, Chem. Commun., 2011, 47, 9005; T. Andrea and M. S. Eisen, Chem. Soc. Rev., 2008, 37, 550; M. Ephritikhine, Organometallics, 2013, 32, 2464; B. M. Gardner and S. T. Liddle, Eur. J. Inorg. Chem., 2013, 3753-3770; H. S. La Pierre and K. Meyer, Prog. Inorg. Chem., 2014, 58, 303-416.

9 I. Castro-Rodriguez and K. Meyer, J. Am. Chem. Soc., 2005, 127, 11242.

10 V. Mougel, C. Camp, J. Pécaut, C. Copéret, L. Maron, C. E. Kefalidis and M. Mazzanti, Angew. Chem., Int. Ed., 2012, 51, 12280-12284; O. Cooper, C. Camp, J. Pécaut, C. E. Kefalidis, L. Maron, S. Gambarelli and M. Mazzanti, J. Am. Chem. Soc., 2014, 136, 6716-6723.

11 O. P. Lam, S. C. Bart, H. Kameo, F. W. Heinemann and K. Meyer, Chem. Commun., 2010, 46, 3137-3139; A.-C. Schmidt, A. V. Nizovtsev, A. Scheurer, F. W. Heinemann and K. Meyer, Chem. Commun., 2012, 48, 8634-8636.

12 N. Tsoureas, O. T. Summerscales, F. G. N. Cloke and S. M. Roe, Organometallics, 2013, 32, 1353-1362.

13 N. Tsoureas, L. Castro, A. F. R. Kilpatrick, F. G. N. Cloke and L. Maron, Chem. Sci., 2014, 5, 3777-3788.
14 A. Elkechai, A. Boucekkine, L. Belkhiri, D. Hauchard, C. Clappe and M. Ephritikhine, C. R. Chim., 2010, 13, 860-869; A. Elkechai, Y. Mani, A. Boucekkine and M. Ephritikhine, Inorg. Chem., 2012, 51, 6943-6952; C. Clappe, D. Leveugle, D. Hauchard and G. Durand, J. Electroanal. Chem., 1998, 448, 95-103.

15 N. Kuhn, G. Henkel, J. Kreutzberg, S. Stubenrauch and C. Janiak, J. Organomet. Chem., 1993, 456, 97-106; M. D. Su and S. Y. Chu, J. Phys. Chem., 1989, 93, 6043-6051; N. M. Kostić and R. F. Fenske, Organometallics, 1983, 2, 1008-1013.

16 S. M. Mansell, N. Kaltsoyannis and P. L. Arnold, J. Am. Chem. Soc., 2011, 133, 9036-9051.

17 F. G. N. Cloke and P. B. Hitchcock, J. Am. Chem. Soc., 2002, 124, 9352-9353.

18 F. Nief, F. Mathey and L. Ricard, Organometallics, 1988, 7, 921-926.

19 C. L. Webster, J. E. Bates, M. Fang, J. W. Ziller, F. Furche and W. J. Evans, Inorg. Chem., 2013, 52, 3565-3572.

20 F. Nief, L. Ricard and F. Mathey, Polyhedron, 1993, 12, 19-26.

21 O. T. Summerscales, F. G. N. Cloke, P. B. Hitchcock, J. C. Green and N. Hazari, J. Am. Chem. Soc., 2006, 128, 9602.

22 Collect, Bruker-AXS, Madison, WI, 1997-2004.

23 Z. Otwinowski and W. Minor, Methods Enzymol., 1997, 276, 307.

24 G. M. Sheldrick, SADABS V2008/1, University of Göttingen, Göttingen, Germany.

25 S. J. Coles and P. A. Gale, Chem. Sci., 2012, 3, 683-689.

26 P. Van Der Sluis and A. L. Spek, Acta Crystallogr., Sect. A: Found. Crystallogr., 1990, 46, 194-201.

27 A. L. Spek, J. Appl. Crystallogr., 2003, 36, 7-13. 